\title{
Direct Conversion of Methane to Higher Hydrocarbons
}

\author{
Kiyoshi Orsuka \\ Department of ('hemical Engineering, 'Tokyo Institute of Technology \\ Ookayama, Meguro-ku, Tokyo 152
}

(Received April 13, 1987)

\begin{abstract}
Recent works in our laboratory on the direct, catalytic conversion of methane into higher hydrocarbons have been reviewed. The topics reviewed are the oxidative coupling of methane to $\mathrm{C}_{2}$ compounds $\left(\mathrm{C}_{22} \mathrm{H}_{6}+\mathrm{C}_{22} \mathrm{H}_{4}\right)$, the selective synthesis of $\mathrm{C}_{22} \mathrm{H}_{4}$, and the synthesis of aromatic hydrocarbons. Among the metal oxides tested, rare earth metal oxides showed high stability, high $\mathrm{C}_{2}$-selectivity, and high catalytic activities for oxidative coupling of $\mathrm{CH}_{4}$. Kinetic studies on oxidative coupling of $\mathrm{CH}_{4}$ over $\mathrm{Sm}_{2} \mathrm{O}_{3}$ suggest that the reaction be initiated by diatomic oxygen species, probably by peroxide ions $\mathrm{O}_{2}{ }^{2-}$. A comparison of the results on the reactions using $\mathrm{O}_{22}$ and $\mathrm{N}_{2} \mathrm{O}$ as oxidants showed that $\mathrm{O}_{2}$ was a better oxidant for catalytic conversion of $\mathrm{CH}_{4}$ into $\mathrm{C}_{2}$ compounds. Alkali halides, especially LiCl, enhanced the selective synthesis of $\mathrm{C}_{2} \mathrm{H}_{4}$ in partial oxidation of $\mathrm{CH}_{4}$ over metal oxides. The effect of $\mathrm{LiCl}$ was most marked for the oxides of the first series transition elements. The role of alkali metals of the alkali halides is to create active compound oxides of the alkali metals and the host metal oxides. The role of halides is to supply halogen atoms which catalyze dehydrogenation of $\mathrm{C}_{2} \mathrm{H}_{6}$ to $\mathrm{C}_{2} \mathrm{H}_{4}$ in the gas phase. The $\mathrm{NaCl} / \mathrm{Mn}$-oxide/silicalite catalyzed the synthesis of higher olefins and aromatics directly from $\mathrm{CH}_{4}$. The combination of a coupling catalyst and an aromatization catalyst improved the synthesis of aromatics with relatively high selectivity $(>16.3 \%)$ and yield $(>5.5 \%)$.
\end{abstract}

\section{Introduction}

Predicted shortage in the supply of crude oil has given natural gas an important position as an alternative source of hydrocarbons. Prospects are good for maintaining secure, reliable and adequate supplies of natural gas at competitive prices well into the future. Currently natural gas is used principally as a fuel in residential, commercial, and industrial services. Industries are now searching for new or novel ways to enhance the use and value of this methane-containing natural resources.

Natural gas generally occurs in remote areas of Siberia, Western Canada, Australia and Asia; thus, its location and transportation pose a major obstacle in its efficient exploitation. It would be extremely valuable if methane, usually comprising over 90 mole\% of the hydrocarbon fraction of natural gas, could be converted into more easily handleable or transportable products such as olefins, aromatics, and higher order hydrocarbons that are used as precursor materials in chemical processing.

$$
n \mathrm{CH}_{4} \longrightarrow \mathrm{C}_{n} \mathrm{H}_{m}
$$

Besides its major use as an energy source, methane is also used, to some extent, as a chemical raw material. One of the largest nonfuel uses of methane is the production of methanol. An innovative process for producing gasoline and light olefins from methanol was developed by Mobil

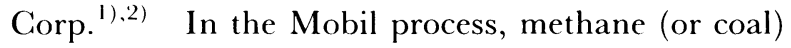
is first converted into synthesis gas which then is converted into methanol by a catalytic process and subsequently into light olefins and higher hydrocarbons using a shape-selective zeolite catalyst (ZSM5). Using methane as a starting carbon source, it is converted into synthesis gas by steam reforming over a nickel catalyst. The steam reforming of methane is a highly endothermic reaction.

$$
\mathrm{CH}_{4}+\mathrm{H}_{2} \mathrm{O} \stackrel{\mathrm{NiO}^{\prime} / \mathrm{Al}_{2} \mathrm{O}_{3}}{\longrightarrow} \mathrm{CO}+3 \mathrm{H}_{2} \quad \Delta H^{\circ}=206 \mathrm{~kJ}
$$

The process, methane to methanol then to light olefins and higher hydrocarbons, suffers from large energy requirements, from complicated engineering steps, and also from inefficiency in oxidation of methane to carbon monoxide and in subsequent reduction of carbon monoxide to methanol and to higher hydrocarbons.

Obviously a direct conversion of methane into 
light olefins and higher hydrocarbons is preferred because it then can yield desired products in one step. However, the conversion of methane into higher hydrocarbons via dehydrogenative coupling and oligomerization is limited due to the following two difficulties: the strength of the carbonhydrogen $(\mathrm{C}-\mathrm{H})$ bond and thermodynamics. Temperatures higher than $1,073 \mathrm{~K}$ are required to effect practical conversion. The combined process consisting of oxidative coupling and oligomerization of methane can surmount these difficulties.

$$
n \mathrm{CH}_{4} \stackrel{\mathrm{O}_{2}}{\longrightarrow} \mathrm{C}_{n} \mathrm{H}_{m}, \mathrm{CO}, \mathrm{CO}_{2}, \mathrm{H}_{2} \mathrm{O}
$$

Under the oxidation conditions that can activate methane in the presence of oxygen, the intermediate products such as light olefins and higher hydrocarbons are quickly oxidized deeply to carbon dioxide and water because both the free energy changes and heats of reaction are favorable for the formation of these final stable products. Only within the last several years, researchers have succeeded in breaking the $\mathrm{C}-\mathrm{H}$ bond and converting methane into useful chemicals by using specially designed catalysts. Detailed information about the past and recent developments in functionalization of methane is available in monographs and reviews. ${ }^{3)}$-8)

This paper selects and reviews our current research activities on the following three topics dealing with partial catalytic oxidation of methane (1) to $\mathrm{C}_{2}$ compounds (ethane and ethylene), (2) to ethylene selectively, and (3) to aromatic hydrocarbons.

\section{Oxidative Coupling}

\subsection{Active and Selective Catalysts}

Since Keller and Bhasin ${ }^{9)}$ reported the possibility of synthesizing $\mathrm{C}_{2}$ compounds $\left(\mathrm{C}_{2} \mathrm{H}_{6}+\mathrm{C}_{2} \mathrm{H}_{4}\right)$ by oxidative coupling of methane over metal oxides, many groups $\left.{ }^{10)}-25\right)$ have begun to work in this area, and there have been increasing industria activities $^{2(6)}$ thereon. Keller and Bhasin" ${ }^{9)}$ tested large numbers of metal oxides to catalyze methane coupling. To minimize the accompanying gasphase noncatalytic reactions, they carried out the reaction by periodic feeding of air and methane. Oxides of $\mathrm{Pb}, \mathrm{Sb}, \mathrm{Tl}, \mathrm{Cd}$, and $\mathrm{Mn}$ were found to be the most active catalysts for the formation of $\mathrm{C}_{2}$ compounds with selectivity of $<50 \%$. However, in the normal, concurrent feeding mode of reactants, none were found to give good selectivity to the desired products.

Hinsen et al. ${ }^{10)}$ reported that catalytic conversion of methane could also be carried out in a con-

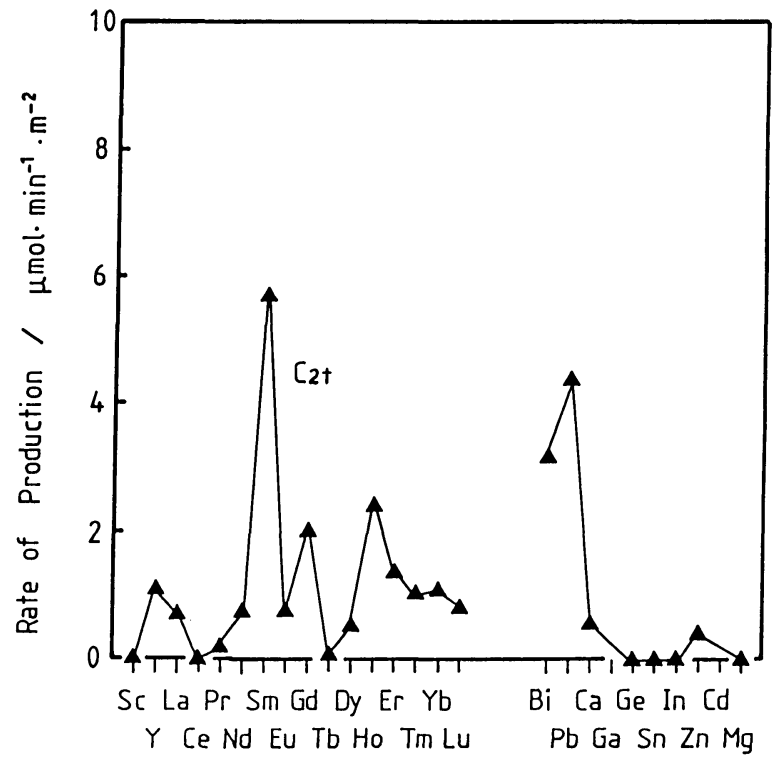

Reaction conditions : $\left.\mathrm{T}=973 \mathrm{~K}, \mathrm{P}(\mathrm{O})_{2}\right)=0.4 \mathrm{kPa}$,

$\mathrm{P}\left(\mathrm{CH}_{1}\right)=18.2 \mathrm{kPa}$, catalyst weight $=0.50 \mathrm{~g}$.

Fig. 1 Catalytic Activities of Metal Oxides in Oxidative Coupling of $\mathrm{CH}_{4}$

tinuously operated catalytic flow reactor when a suitable catalyst and suitable reaction conditions were chosen. They found that catalyst $\mathrm{PbO} /$ $\mathrm{Al}_{2} \mathrm{O}_{3}$ was the most active. $\mathrm{PbO}$ on $\mathrm{SiO}_{2}$ carrier was most effective for $\mathrm{C}_{2}$-selectivity approaching $72 \%$, but its catalytic activity was low. ${ }^{10)}$

Recent work in our laboratory ${ }^{11), 18)}$ has demonstrated that rare earth metal oxides exhibited better catalytic activity and selectivity in the oxidative coupling of methane. Fig. 1 shows catalytic activities (rate per surface area of catalyst) for the formations of $\mathrm{C}_{2}$ compounds $\left(\mathrm{C}_{2} \mathrm{H}_{4}+\mathrm{C}_{2} \mathrm{H}_{6}\right)$ examined for various rare earth metal oxides, $\mathrm{PbO}$, $\mathrm{Bi}_{2} \mathrm{O}_{3}, \mathrm{SnO}_{2}, \mathrm{Ga}_{2} \mathrm{O}_{3}, \mathrm{GeO}_{2}, \mathrm{In}_{2} \mathrm{O}_{3}, \mathrm{ZnO}, \mathrm{CdO}$, $\mathrm{CaO}$, and $\mathrm{MgO}$ (all in powder form) under the experimental conditions shown in the figure caption. All experiments were performed using a fixed-bed reactor with a conventional gas-flow system. Activities of the metal oxides, which have already been reported to be good catalysts for the reaction, ${ }^{9)}{ }^{10)}$ are shown on the right side in Fig. 1. The products were $\mathrm{C}_{2} \mathrm{H}_{6}, \mathrm{C}_{2} \mathrm{H}_{4}, \mathrm{CO}, \mathrm{CO}_{2}$, and $\mathrm{H}_{2} \mathrm{O}$. The results in Fig. 1 show that the specific activity for the formation of $\mathrm{C}_{2}$ compounds is the highest for $\mathrm{Sm}_{2} \mathrm{O}_{3}$. The selectivity to $\mathrm{C}_{2} \mathrm{H}_{6}$ and $\mathrm{C}_{2} \mathrm{H}_{4}$ calculated on the basis of carbon number of the $\mathrm{CH}_{4}$ reacted for the same experiments in Fig. 1 are plotted in Fig. 2. Fig. 2 indicates that the oxides giving higher than $70 \%$ selectivity to $\mathrm{C}_{2}$ compounds $\left(\mathrm{C}_{2} \mathrm{H}_{4}+\mathrm{C}_{2} \mathrm{H}_{6}\right.$ denoted by $\left.\mathrm{C}_{2}\right)$ are the rare 


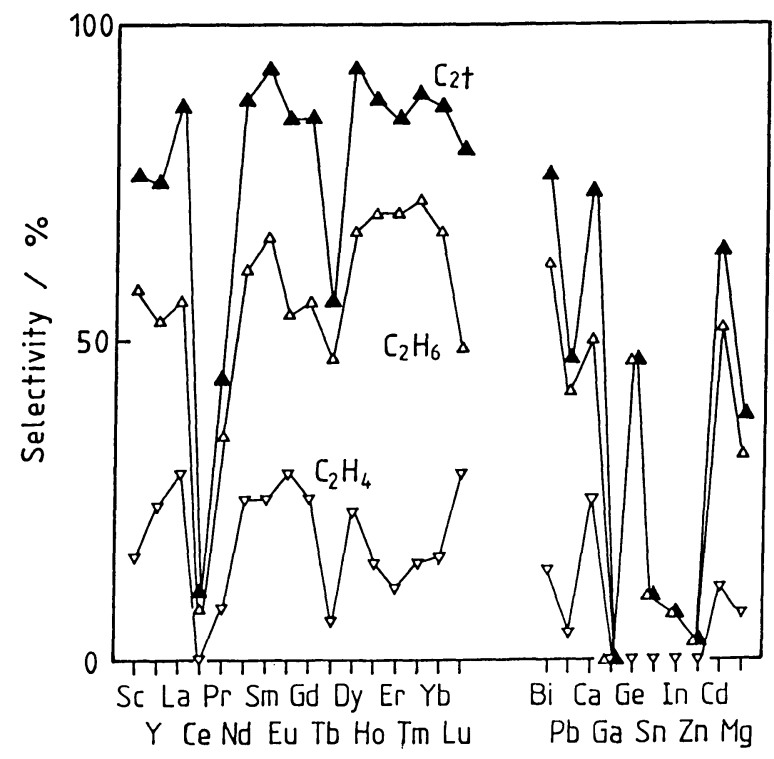

Fig. 2 Selectivities to $\left(\ldots, \mathrm{H}_{6},\left(\ldots, \mathrm{H}_{1}\right.\right.$, and the sum of the $(i$, , Ciompounds

earth metal oxides (except for $\mathrm{Ce}, \mathrm{Pr}$, and $\mathrm{Tb}$ ), $\mathrm{Bi}_{2} \mathrm{O}_{3}$, and $\mathrm{CaO}$. In general, lanthanide oxides, including lanthanum itself, showed particularly high $\mathrm{C}_{2}$-selectivity $(>80 \%)$. The selectivity observed for $\mathrm{Sm}_{2} \mathrm{O}_{3}$ and for $\mathrm{Dy}_{2} \mathrm{O}_{3}$ reached to $93 \%$.

The catalytic tests performed under the same conditions have been extended to all the stable oxides of the metals in the periodic table. Many metal oxides showed higher catalytic activity than that of $\mathrm{Sm}_{2} \mathrm{O}_{3}$ and $\mathrm{PbO}$ as far as the conversion of methane was concerned, but they gave mostly deep oxidation products with low $\mathrm{C}_{2}$-selectivity of less than $3 \%$. The oxides in Fig. 2 are believed to have basic or amphoteric properties. Generally, basic oxides showed high selectivity to the formation of $\mathrm{C}_{2}$-hydrocarbons. . $^{\text {- }}$-21)

As mentioned above, $\mathrm{Sm}_{2} \mathrm{O}_{3}$ was the most active and selective catalyst among the metal oxides examined under the experimental conditions shown in Fig. 1. However, conditions such as low oxygen pressure $(0.4 \mathrm{kPa})$, high $\mathrm{P}\left(\mathrm{CH}_{4}\right): \mathrm{P}\left(\mathrm{O}_{2}\right)$ ratio (45), and low reactant flow rate $\left(4.5 \mathrm{~m} l \cdot \min ^{-1}\right)$ used for the catalyst tests were not suitable for evaluating the true catalytic activity of $\mathrm{Sm}_{2} \mathrm{O}_{3}$ because the oxygen conversion exceeded $95 \%$. Therefore, the catalytic test of $\mathrm{Sm}_{2} \mathrm{O}_{3}$ was performed under higher $\mathrm{P}\left(\mathrm{O}_{2}\right)$, lower $\mathrm{P}\left(\mathrm{CH}_{4}\right): \mathrm{P}\left(\mathrm{O}_{2}\right)$, and higher flow rate than those conditions shown in Fig. 1. Fig. 3 shows the effect of W/F (weight of catalyst/ flow rate of reactants) on $\mathrm{C}_{2}$-STY (space time yield of $\mathrm{C}_{2}$ compounds), on $\mathrm{C}_{2}$-yield, on selectivity to
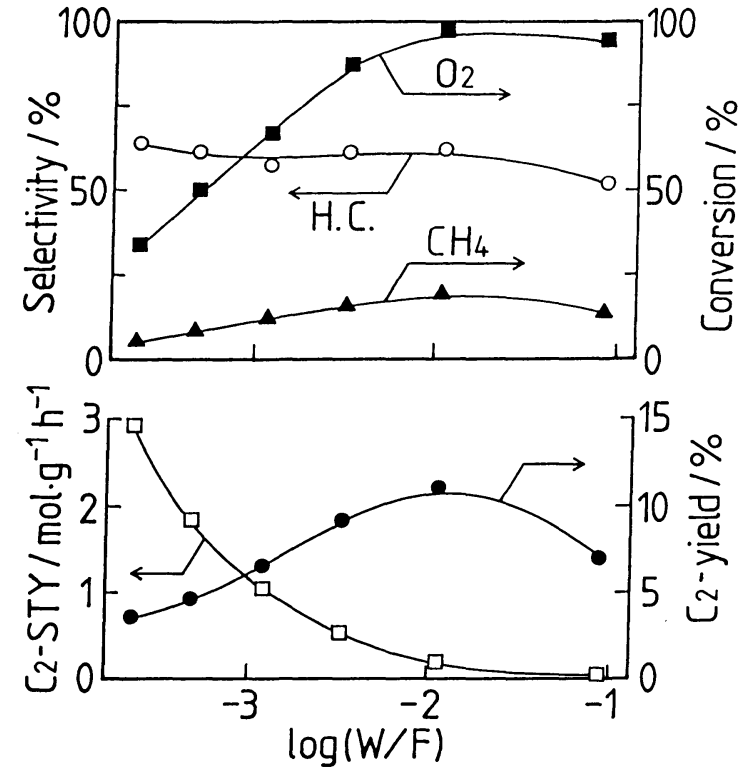

Reaction conditions : $\mathrm{T}=1,023 \mathrm{~K}, \mathrm{P}\left(\mathrm{CH}_{1}\right) / \mathrm{P}\left(\mathrm{O}_{2}\right)$ $=6, \mathrm{~W}=0.010-0.150 \mathrm{~g}, \mathrm{~F}=1.68-45.0 / \cdot \mathrm{h} \quad$.

Fig. 3 The Effect of $\mathrm{W} / \mathrm{F}$ on the Reaction over $\mathrm{Sm}_{2} \mathrm{O}_{3}$

higher hydrocarbons, on $\mathrm{CH}_{4}$-conversion, and on $\mathrm{O}_{2}$-conversion. The $\mathrm{O}_{2}$-conversion decreased at $\mathrm{W} / \mathrm{F}$ lower than $0.01 \mathrm{~g} \cdot \mathrm{h} \cdot \mathrm{l}^{-1}$. The $\mathrm{C}_{2}$-STY increased remarkably by lowering $\mathrm{W} / \mathrm{F}$. The $\mathrm{C}_{2^{-}}$ STY reached $2.98 \mathrm{~mol} \cdot \mathrm{g}^{-1} \cdot \mathrm{h}^{-1}$ at $\mathrm{W} / \mathrm{F} 0.000223$ $\mathrm{g} \cdot \mathrm{h} \cdot \mathrm{l}^{-1}$. The selectivity to the coupling products (mostly $\mathrm{C}_{2}$ compounds) at this $\mathrm{W} / \mathrm{F}$ was fairly high $(64 \%)$.

The $\mathrm{C}_{2}$-STYs and $\mathrm{C}_{2}$-selectivities reported recently for different catalysts are summarized in Table 1. ${ }^{27)}$ Since the experimental conditions used for testing $\mathrm{C}_{2}$-STYs are so different from each other as can be seen in the table, we cannot compare the true catalytic activity of the catalysts. The $\mathrm{C}_{2}-\mathrm{STY} \mathrm{S}_{\mathrm{S}}$ listed in Table $\mathbf{1}$ for the catalysts examined by other researchers must increase greatly when $\mathrm{W} / \mathrm{F}$ is lowered than the values indicated in column seven. However, at this moment, the $\mathrm{C}_{2}$ STY observed for $\mathrm{Sm}_{2} \mathrm{O}_{3}$ is from one to three orders of magnitude greater than the values reported previously.

No appreciable decreases in activity and selectivity were observed for $\mathrm{Sm}_{2} \mathrm{O}_{3}$ after $180 \mathrm{~h}$ of operation at $973 \mathrm{~K} . \quad \mathrm{Sm}_{2} \mathrm{O}_{3}$ was a very stable catalyst for oxidative conversion of methane. High stability, high $\mathrm{C}_{2}$-selectivity, and high catalytic activity observed for $\mathrm{Sm}_{2} \mathrm{O}_{3}$ suggest that this oxide be one of the most promising catalysts for converting natural gas into ethane and ethylene. The catalytic tests performed at low $\mathrm{W} / \mathrm{Fs}$ for other rare earth 
Table 1 Comparison of the Activities of Catalysts for Oxidative Coupling of $\mathrm{CH}_{4}$

\begin{tabular}{|c|c|c|c|c|c|c|c|}
\hline Catalyst & $\frac{\mathrm{C}_{2}-\mathrm{STYY}}{\mathrm{mmol} \cdot \mathrm{g}^{--1} \cdot \mathrm{h}^{-1}}$ & $\begin{array}{c}\mathrm{C}_{i_{2}} \text {-select. } \\
\%\end{array}$ & $\underset{{ }^{\circ} \mathrm{C}}{\text { Temp. }}$ & $\underset{\mathrm{kPa}}{\mathrm{P}\left(\mathrm{CH}_{4}\right)}$ & $\mathrm{P}\left(\mathrm{CH}_{4}\right) / \mathrm{P}\left(\mathrm{O}_{2}\right)$ & $\begin{array}{c}\mathrm{W} / \mathrm{F} \\
\mathrm{g} \cdot \mathrm{h} \cdot l^{-1}\end{array}$ & Ref. No. \\
\hline $\mathrm{PbC} / \mathrm{SiO}$, & 1.2 & 71.4 & 740 & 70 & 10 & 0.43 & 10 \\
\hline $\mathrm{Li} / \mathrm{MgC}$ & 0.9 & 46.5 & 720 & 29 & 1.9 & 1.3 & 13 \\
\hline $\mathrm{PbO} / \mathrm{MgO}$ & 11.1 & 85.3 & 750 & 61 & 37.8 & 0.045 & 22 \\
\hline LaAlO & 62.3 & 78 & 710 & 88 & 33.3 & 0.017 & 20 \\
\hline $\mathrm{L}$ i/Mn-oxide & 13.5 & 43 & 750 & 57 & 2.0 & 0.167 & 15 \\
\hline $\mathrm{K} / \mathrm{BaC}_{\mathrm{a}} \mathrm{O}_{3}$ & 0.21 & 42 & 800 & 2.8 & 2.0 & 22.2 & 21 \\
\hline $\mathrm{L}, \mathrm{i} / / \mathrm{n} \mathrm{O})$ & 3.31 & 61 & 740 & 55 & 2.1 & 0.67 & 23 \\
\hline $\mathrm{K} / \mathrm{Bi} / \mathrm{Al}_{2}, \mathrm{O}_{3}$ & 90 & 30 & 700 & 51 & 10 & 0.0029 & 24 \\
\hline $\mathrm{BaO} / \mathrm{CaO}$ & 20.9 & 61 & 800 & 40 & 5.0 & 3.39 & 25 \\
\hline $\mathrm{Sm}_{2} \mathrm{O}_{3}$ & 527 & 61 & 750 & 87 & 6.0 & 0.0033 & 27 \\
\hline $\mathrm{Sm}_{2}, \mathrm{O}$ & 2,980 & 60 & 750 & 87 & 6.0 & 0.000223 & 27 \\
\hline
\end{tabular}

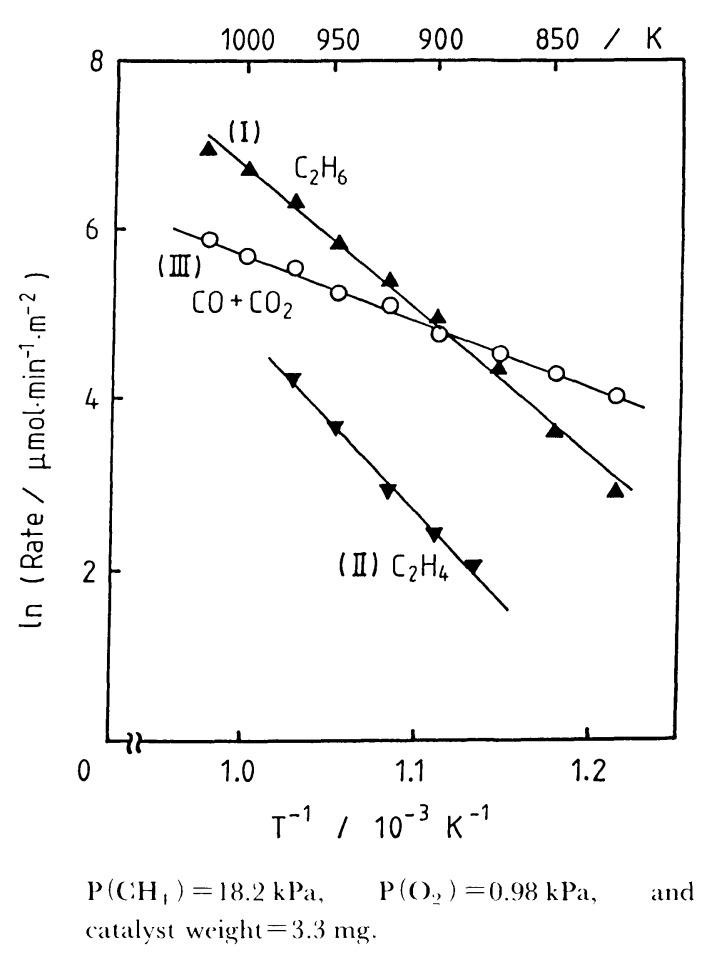

Fig. 4 Temperature Effects on the Rates of Formations of the Products over Sm, $\mathrm{Sm}_{3}$

metal oxides such as $\mathrm{L}_{2} \mathrm{O}_{3}, \mathrm{Nd}_{2} \mathrm{O}_{3}, \mathrm{Dy}_{2} \mathrm{O}_{3}$, and $\mathrm{Eu}_{2} \mathrm{O}_{3}$ showed that catalytic activities of these oxides were also very high and comparable to the activity of $\mathrm{Sm}_{2} \mathrm{O}_{33}$. In general the rare earth metal oxides were stable at high temperatures. Thus, the use of cheaper oxides $\mathrm{La}_{2} \mathrm{O}_{3}$ or $\mathrm{Nd}_{2} \mathrm{O}_{3}$ should be of practical advantage in converting methane into $\mathrm{C}_{2}$. compounds.

\subsection{Kinetic Studies}

Kinetic studies on the reaction over $\mathrm{Sm}_{2} \mathrm{O}_{3}$ were carried out to see the general features of oxidative coupling of methane catalyzed by metal oxides. $^{18), 191}$

\section{(1) Temperature Effects}

Temperature effects on the rates of formation of

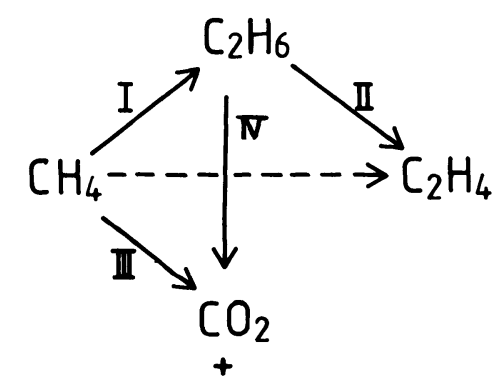

CO

Fig. 5 Overall Reaction Scheme

products are shown in Fig. 4. ${ }^{13)}$ The $\mathrm{O}_{2-}$ conversion was controlled less than $5 \%$ at $\leq 973$ $\mathrm{K}$. The apparent activation energies calculated from the straight lines for the $\mathrm{C}_{2}$ compounds $\left(\mathrm{C}_{2} \mathrm{H}_{6}\right.$ $\left.+\mathrm{C}_{2} \mathrm{H}_{4}\right)$, ethylene, and carbon oxides $(\mathrm{CO}+$ $\left.\mathrm{CO}_{2}\right)^{18)}$ were 135,173 , and $66 \mathrm{~kJ} \mathrm{~mol}^{-1}$, respectively. The higher activation energy for the synthesis of $\mathrm{C}_{2}$ compounds than that for carbon oxides shows that the higher the temperature the better is the selectivity to and the yield of $\mathrm{C}_{2}$ compounds. The highest activation energy for the formation of ethylene indicates that the selectivity to ethylene becomes favorable as temperature increases. Experiments using different hydrocarbons, i.e., $\mathrm{CH}_{4}, \mathrm{C}_{2} \mathrm{H}_{6}$, and $\mathrm{C}_{2} \mathrm{H}_{4}$ as the starting reactants showed that the overall reaction scheme for oxidation of methane at low conversion levels could be as shown in Fig. 5. The direct synthesis of ethylene (the dotted arrow) was negative. The unexpected observation that the selectivity to $\mathrm{C}_{2}$ compounds became favorable with increasing temperature was also confirmed for all of the rare earth metal oxides in Fig. 1, for $\mathrm{Li} / \mathrm{MgO}^{12)}$, for $\mathrm{PbO} / \mathrm{MgO}^{22)}$, and for $\mathrm{K} / \mathrm{Bi}^{2} / \mathrm{Al}_{2} \mathrm{O}_{3}{ }^{24)}$. This fact implies that a common reaction mechanism is involved in the reactions over these basic metal oxides. 


\section{(2) Pressure Effects}

The effects of oxygen pressure on the rates of products over $\mathrm{Sm}_{2} \mathrm{O}_{3}$ at $973 \mathrm{~K}$ are shown in Fig. 6. $^{18), 19)}$ The $\mathrm{C}_{2}$-selectivity decreases steadily with increasing oxygen pressure. However, the selectivity which is quite high at low $\mathrm{P}\left(\mathrm{O}_{2}\right)$ attains $100 \%$ at $\mathrm{P}\left(\mathrm{O}_{2}\right) 0.3 \mathrm{kPa}$. Fig. 7 shows the effect of $\mathrm{CH}_{4}$ pressure. Both the rate and $\mathrm{C}_{2}$-selectivity increased with increasing $\mathrm{CH}_{4}$ pressure.

Pressure effects were also examined at 873, 923, and $1,023 \mathrm{~K}$. At each temperature, the following

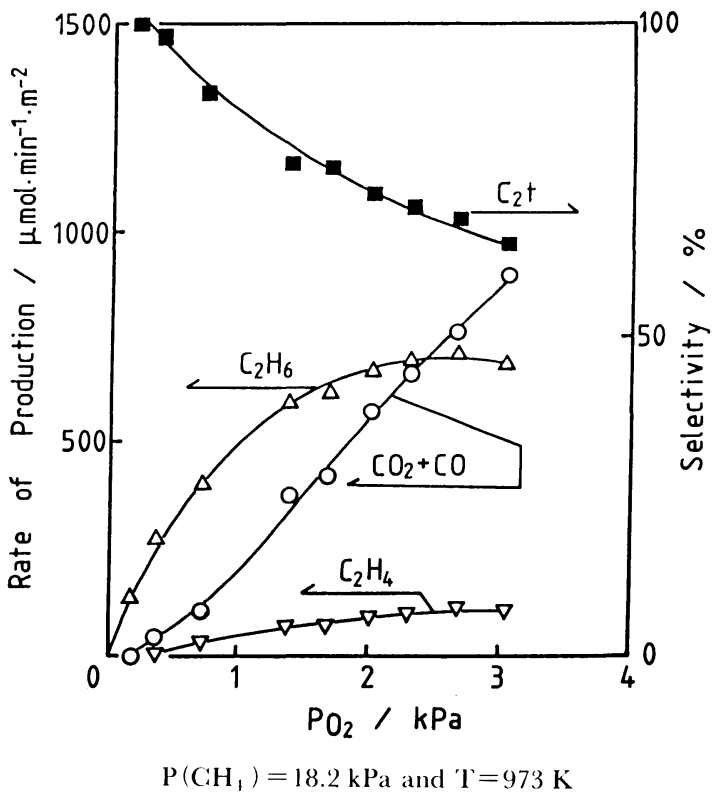

Fig. $6 \mathrm{P}\left(\mathrm{O}_{2}\right)$ Effects on the Rate and $\mathrm{C}_{12}$-selectivity

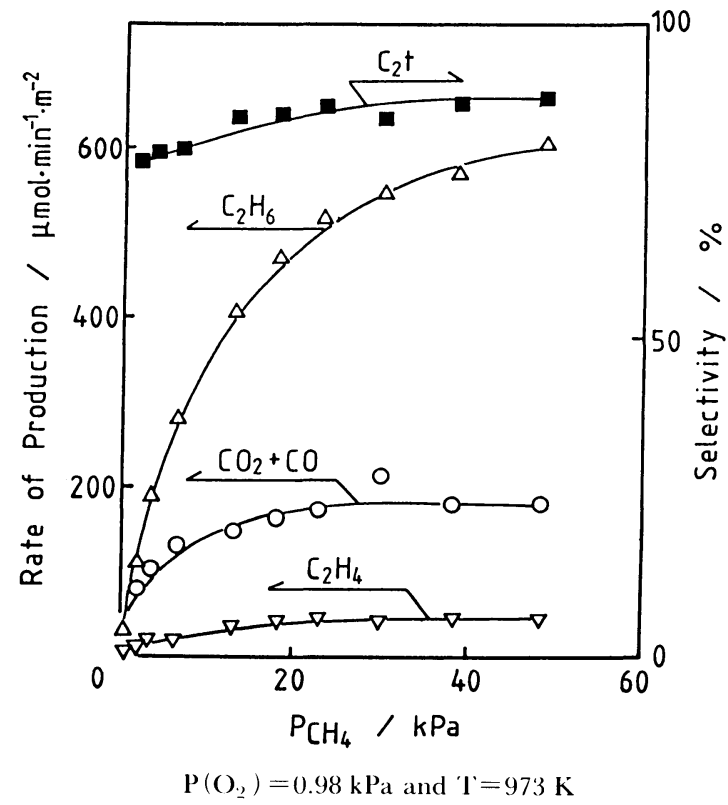

Fig. $7 \mathrm{P}\left(\mathrm{CH}_{4}\right)$ Effects on the Rate and $\mathrm{C}_{2,2}$-selectivity rate equation fitted the rate of methane conversion $\left(r_{\mathrm{c}}\right):^{19)}$

$$
r_{\mathrm{c}}=k \frac{K_{\mathrm{m}} \mathrm{P}\left(\mathrm{CH}_{4}\right)}{1+K_{\mathrm{m}} \mathrm{P}\left(\mathrm{CH}_{4}\right)} \cdot \frac{K_{\mathrm{o}} \mathrm{P}\left(\mathrm{O}_{2}\right)}{1+K_{0} \mathrm{P}\left(\mathrm{O}_{2}\right)}
$$

where, $k, K_{\mathrm{m}}$, and $K_{\mathrm{o}}$ are the constants at fixed temperatures.

\section{(3) Reaction Mechanism}

The above rate equation was well explained by assuming the following reaction mechanism: ${ }^{19)}$

$$
\begin{aligned}
& \mathrm{CH}_{4}(\mathrm{~g}) \stackrel{\kappa_{m}}{\longrightarrow} \mathrm{CH}_{4}{ }^{*} \\
& \mathrm{O}_{2}(\mathrm{~g}) \stackrel{\kappa_{0}}{\longrightarrow} \mathrm{O}_{2}{ }^{*} \\
& \mathrm{CH}_{4}{ }^{*}+\mathrm{O}_{2}{ }^{*} \stackrel{k}{\longrightarrow} \mathrm{CH}_{3}+\mathrm{HO}_{2} \\
& \mathrm{CH}_{3}+\mathrm{CH}_{3} \longrightarrow \mathrm{C}_{2} \mathrm{H}_{6} \\
& \mathrm{CH}_{3}+\mathrm{O}_{2} \longrightarrow \mathrm{CH}_{3} \mathrm{O}_{2} \longrightarrow \mathrm{CO}, \mathrm{CO}_{2}
\end{aligned}
$$

where, the superscript $\left(^{*}\right)$ means excited molecules (vibrational, electronical, or charged) generated on the surface or generated by collision with the surface. The $\mathrm{C}-\mathrm{H}$ bond breaking (iii) is the ratedetermining step in the overall reaction. Here, it is to be noted that initiation (step iii) is caused not by a monoatomic oxygen but by a diatomic oxygen. The coupling of two $\mathrm{CH}_{3}$ radicals (or alternatively $\mathrm{CH}_{3}$-groups adsorbed) produces ethane (step iv). Deep oxidation takes place through the oxidation of $\mathrm{CH}_{3}$ radicals (or groups) (step v). Reactions iv and $\mathrm{v}$ may occur either on the surface of $\mathrm{Sm}_{2} \mathrm{O}_{3}$ or in the gas phase near the surface. ${ }^{19), 28)}$ Oxidative dehydrogenation of the $\mathrm{C}_{2} \mathrm{H}_{6}$ formed gives $\mathrm{C}_{2} \mathrm{H}_{4}$ as described in Fig. 5 .

The $\mathrm{C}_{2}$-selectivity is determined by the competition between reactions iv and $v$. The decrease in the $\mathrm{C}_{2}$-selectivity with increasing $\mathrm{P}\left(\mathrm{O}_{2}\right)$ (Fig. 6) can be ascribed to the increase in the rate of reaction $\mathrm{v}$ compared to the rate of reaction iv.

The temperature effect on the selectivity of the products (Fig. 4) indicated that the higher the temperature the better was the selectivity to $\mathrm{C}_{2}$, compounds. Since the abstraction of $\mathrm{H}$ from $\mathrm{CH}_{4}$ (reaction iii) requires a large activation energy (149 $\mathrm{kJ} \mathrm{mol}{ }^{-1}$ ), ${ }^{19)}$ the concentration of $\mathrm{CH}_{3}$ radicals (or methyl groups) must increase sharply with the rise in temperature. Note that the rate of reaction iv depends on the square of $\mathrm{CH}_{3}$ concentrations, but the rate of deep oxidation (reaction $\mathrm{v}$ ) is proportional to $\mathrm{CH}_{3}$ concentration. Thus, acceleration in the rate of $\mathrm{C}_{2}$-formation with temperature is greater than that of deep oxidation. This observation explains the higher $\mathrm{C}_{2}$-selectivity at higher temperatures. 


\subsection{Oxidative Coupling of Methane using $\mathrm{N}_{2} \mathrm{O}$}

With certain catalysts and under certain reaction conditions, partial oxidation of methane can be achieved successfully when nitrous oxide is used as the oxygen source. ${ }^{29)-32)}$ Therefore, we have compared the results of oxidative coupling of methane using $\mathrm{O}_{2}$ and $\mathrm{N}_{2} \mathrm{O}$ over rare earth metal oxides. $^{33), 34)}$ The results at relatively high pressures of the oxidants $\left(\mathrm{P}\left(\mathrm{O}_{2}\right)=\mathrm{P}\left(\mathrm{N}_{2} \mathrm{O}\right)=10.5 \mathrm{kPa}\right.$, $\left.\mathrm{P}\left(\mathrm{CH}_{4}\right)=48.8 \mathrm{kPa}\right)$ are shown in Figs. 8 and 9 . The conversions of the oxidants in Fig. 8 show that the reactivity of $\mathrm{O}_{2}$ is greater than that of $\mathrm{N}_{2} \mathrm{O}$ for most of the oxides tested.

As can be seen in Fig. 9, the selectivity to the coupling products is higher when $\mathrm{N}_{2} \mathrm{O}$ is used for all the rare earth metal oxides tested. In general, temperatures higher than $873 \mathrm{~K}$ are required for producing higher hydrocarbons $\left(\geq \mathrm{C}_{2}\right)$ when $\mathrm{O}_{2}$ is used as an oxidant. However, when $\mathrm{N}_{2} \mathrm{O}$ is used, the temperature effect on the selectivity to higher hydrocarbons is not so apparent especially for $\mathrm{Pr}_{6} \mathrm{O}_{11}, \quad \mathrm{Nd}_{2} \mathrm{O}_{3}, \quad \mathrm{Sm}_{2} \mathrm{O}_{3}$, and $\mathrm{Dy}_{2} \mathrm{O}_{3}$ (Fig. 9). Thus, $\mathrm{N}_{2} \mathrm{O}$ is a peculiar oxidant causing a selective

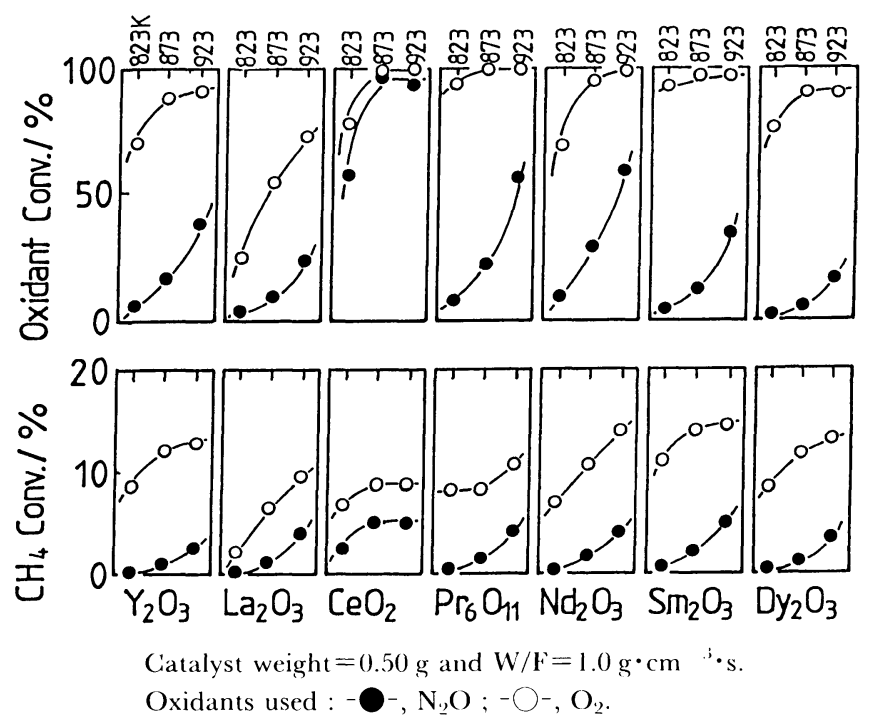

Fig. 8 Conversions of $\mathrm{CH}_{4}$ and Oxidants in Partial Oxidation of $\mathrm{CH}_{4}$ over Rare Earth Metal Oxides at 823,873 ! and $923 \mathrm{~K}$

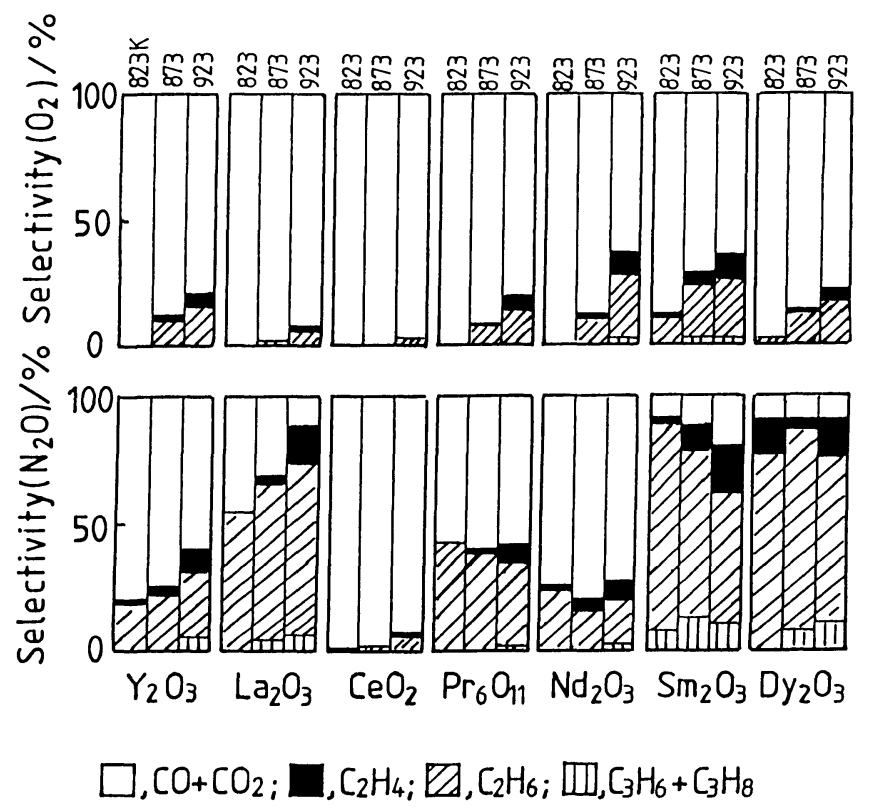

Experimental conditions are the same as those in Fig. 8.

Oxidants : upper row, $\mathrm{O}_{2}$ : lawer row, $\mathrm{N}_{2} \mathrm{O}$.

Fig. 9 Product Distributions (Selectivities) in Partial Oxidation of $\mathrm{CH}_{4}$ 
coupling of methane at temperatures lower than $873 \mathrm{~K}$. The effects of pressure of the oxidants on the rate and selectivity to the products were examined for $\mathrm{Sm}_{2} \mathrm{O}_{3}$ at temperature as low as 823 $\mathrm{K} .{ }^{34)}$ Although only a trace of ethane was formed at $\mathrm{O}_{2}$-pressure greater than $2 \mathrm{kPa}$, the $\mathrm{C}_{2}$-yield increased sharply when $\mathrm{O}_{2}$ pressure decreased below $0.6 \mathrm{kPa}$. On the other hand, the rate of formation of $\mathrm{C}_{2}$ compounds was not affected by change in $\mathrm{N}_{2} \mathrm{O}$ pressure. The maximum yield of $\mathrm{C}_{2} \mathrm{H}_{6}$ observed when $\mathrm{O}_{2}$ was used as the oxidant was much greater than when $\mathrm{N}_{2} \mathrm{O}$ was used. These results indicate that $\mathrm{O}_{2}$ is a better oxidant for the catalytic conversion of methane into $\mathrm{C}_{2}$ compounds.

Detailed kinetic studies on the reaction using $\mathrm{N}_{2} \mathrm{O}$ as the oxidant suggested that the reaction mechanism be quite different from the case in which $\mathrm{O}_{2}$ was used as the oxidant. ${ }^{34)}$ Decomposition of $\mathrm{N}_{2} \mathrm{O}$ over $\mathrm{Sm}_{2} \mathrm{O}_{3}$ was proposed to be rate-determining.

\subsection{Oxygen Species Responsible for Activat- ing Methane}

Only a few reports on the fundamental work concerning the oxygen species responsible for activating methane over metal oxides are available. Liu et al. ${ }^{30)}$ have demonstrated that surface $\mathrm{O}^{-}$ ions are the active oxygen for initiating partial oxidation of methane over $\mathrm{MoO}_{3} / \mathrm{Cab}-\mathrm{O}$-Sil using $\mathrm{N}_{2} \mathrm{O}$ as an oxidant. Ito et al. ${ }^{13)}$ have suggested the $\left[\mathrm{Li}^{+} \mathrm{O}^{-}\right]$centers were responsible for abstracting $\mathrm{H}$ from $\mathrm{CH}_{4}$ over Li-promoted $\mathrm{MgO}$. As mentioned earlier, the kinetic studies on oxidative coupling of methane suggest that a diatomic oxygen be responsible for the activation of methane (reaction iii). The idea that the oxidation of methane is initiated by diatomic oxygens is generally accepted for gas phase reactions. ${ }^{35), 36)}$ The kinetic studies described earlier, however, cannot specify the kind of diatomic oxygen species responsible for the reaction over $\mathrm{Sm}_{2} \mathrm{O}_{3}$. The species may perhaps be $\mathrm{O}_{2}{ }^{-}, \mathrm{O}_{2}{ }^{2-}$, or a chemically adsorbed $\mathrm{O}_{2}$ on the surface.

Lunsford and coworkers ${ }^{37), 38)}$ have implied that the active oxygen species over $\mathrm{La}_{2} \mathrm{O}_{3}$ may be a superoxide ions $\mathrm{O}_{2}{ }^{-}$. Recently we have demonstrated that the reactions of $\mathrm{CH}_{4}$ with $\mathrm{Na}_{2} \mathrm{O}_{2}$, $\mathrm{BaO}_{2}$, and $\mathrm{SrO}_{2}$ proceed smoothly, yielding $\mathrm{C}_{2}$ compounds with high selectivity at $<673 \mathrm{~K}^{39)}$ This observation indicates that the peroxide ions $\mathrm{O}_{2}{ }^{2-}$ on the surface are very reactive for $\mathrm{C}-\mathrm{H}$ bond breaking. ESR spectra for the $\mathrm{Na}_{2} \mathrm{O}_{2}$ sam- ple used in the experiments showed that the sample contained superoxide $\mathrm{O}_{2}{ }^{-}$ions. However, no correlation between the $\mathrm{O}_{2}{ }^{-}$and activation of methane was observed. ${ }^{39)}$ Therefore, we suggested that the dioxygen species responsible for initiating the abstraction of $\mathrm{H}$ from $\mathrm{CH}_{4}$ over $\mathrm{Sm}_{2} \mathrm{O}_{3}$ could be $\mathrm{O}_{2}{ }^{2-}$.

\section{Direct Conversion of Methane to Ethylene}

\subsection{Alkali Halides/Transition Metal Oxides}

Ethylene is one of the major raw materials in chemical industry. As described earlier (Fig. 5), ethylene is formed stepwise from methane to ethane and finally to ethylene $\left(\mathrm{CH}_{4} \rightarrow \mathrm{C}_{2} \mathrm{H}_{6} \rightarrow\right.$ $\mathrm{C}_{2} \mathrm{H}_{4}$ ). Usually, in oxidative coupling of methane, the selectivity to ethylene is relatively low compared to the selectivity to ethane because the ethane is mainly oxidized to $\mathrm{CO}$ and $\mathrm{CO}_{2}$ with low selectivity to ethylene. The high $\mathrm{C}_{2} \mathrm{H}_{4} / \mathrm{C}_{2} \mathrm{H}_{6}$ ratio in the $\mathrm{G}_{2}$-products is of great advantage since no further process to convert ethane to ethylene is required. Therefore, catalysts converting methane into ethylene with higher selectivity and yield are strongly desired. Thus, we have looked for catalysts which give ethylene directly from methane with high one-pass conversion and yield. ${ }^{15), 16), 17)}$

Enhancing effects of alkali metals on oxidative coupling of methane have been first reported by Hinsen et al. ${ }^{10)}$ for $\mathrm{PbO} / \mathrm{Al}_{2} \mathrm{O}_{3}$. The promoting effects of alkali metals have also been observed for $\mathrm{MgO},{ }^{12), 13), 21)} \quad \mathrm{Sm}_{2} \mathrm{O}_{3},{ }^{14)} \mathrm{ZnO},{ }^{23)}$ and $\mathrm{Bi}_{2} \mathrm{O}_{3} /$ $\mathrm{Al}_{2} \mathrm{O}_{3} \cdot{ }^{24)}$ Among the alkali salt additives tested, we found lithium chloride exerted the most favorable effect on the reaction over $\mathrm{Sm}_{2} \mathrm{O}_{3}$, since it increased not only the yields of $\mathrm{C}_{2}$ compounds but also the ratio of $\mathrm{C}_{2} \mathrm{H}_{4} / \mathrm{C}_{2} \mathrm{H}_{6}$. This favorable effect of LiCl was observed for many other metal oxides $\left(\mathrm{Eu}_{2} \mathrm{O}_{3}, \mathrm{La}_{2} \mathrm{O}_{3}, \mathrm{CeO}_{2}, \mathrm{MgO}, \mathrm{CaO}, \mathrm{SiO}_{2}, \mathrm{Al}_{2} \mathrm{O}_{3}\right.$, $\mathrm{ZrO}_{2}, \mathrm{Nb}_{2} \mathrm{O}_{5}, \mathrm{Ga}_{2} \mathrm{O}_{3}, \mathrm{GeO}_{2}, \mathrm{In}_{2} \mathrm{O}_{3}, \mathrm{SnO}_{2}, \mathrm{PbO}$, $\mathrm{Bi}_{2} \mathrm{O}_{3}, \mathrm{TiO}_{2}, \mathrm{~V}_{2} \mathrm{O}_{5}, \mathrm{Cr}_{2} \mathrm{O}_{3}, \mathrm{MnO}_{2}, \mathrm{Fe}_{2} \mathrm{O}_{3}, \mathrm{Co}_{3} \mathrm{O}_{4}$, $\mathrm{NiO}, \mathrm{CuO}$, and $\mathrm{ZnO}$ ). Among the oxides tested, however, the enhancing effect of LiCl on the yield of ethylene was most marked for the oxides of the first series transition elements. ${ }^{15), 17)}$

Table 2 shows the results observed for the transition metal oxides ${ }^{15)}$ when the reactants were on stream for $20 \mathrm{~min}$. The metal oxides without LiGl catalyzed only deep oxidation of methane. However, as can be seen in Table 2, high $\mathrm{C}_{22}$-yields were observed for the oxides of $\mathrm{Ti}, \mathrm{Mn}, \mathrm{Co}, \mathrm{Ni}$, $\mathrm{Cu}$, and $\mathrm{Zn}$ in the presence of $\mathrm{LiCl}$. The $\mathrm{C}_{2}$-yield observed for $\mathrm{LiCl} / \mathrm{Mn}$-oxide has been the highest 
Table 2 Synthesis of $\mathrm{C}_{2} \mathrm{H}_{4}$ from $\mathrm{CH}_{4}$ over $\mathrm{LiCl} /$ Transition Metal Oxides

\begin{tabular}{|c|c|c|c|c|c|c|}
\hline Catalyst & $\begin{array}{c}\% \mathrm{CH}_{4} \\
\text { conversion }\end{array}$ & $\begin{array}{c}\% \mathrm{O}_{2} \\
\text { conversion }\end{array}$ & $\begin{array}{c}\% \mathrm{C}_{2} \mathrm{H}_{4} \\
\text { selectivity }\end{array}$ & $\begin{array}{c}\% \mathrm{C}_{2} \mathrm{H}_{6} \\
\text { selectivity }\end{array}$ & $\begin{array}{l}\% \mathrm{C}_{2} \\
\text { yield }\end{array}$ & $\begin{array}{c}\% \mathrm{C}_{2} \mathrm{H}_{4} \\
\text { yield }\end{array}$ \\
\hline Licil/Ti-oxide & 17.6 & 40 & 77.1 & 5.7 & 14.6 & 13.6 \\
\hline I.iCl/Cir-oxide & 26.1 & 85 & 0 & 0 & 0 & 0 \\
\hline LiCI/Mn-oxide & 47.3 & 95 & 59.4 & 5.3 & 30.6 & 28.1 \\
\hline I.iCl/Fe-oxide & 22.2 & 92 & 0 & 0 & 0 & 0 \\
\hline $\mathrm{LiCl} / \mathrm{Co}$-oxide & 48.0 & 91 & 32.1 & 3.4 & 17.0 & 15.4 \\
\hline $\mathrm{LiCI} / \mathrm{Ni}$-oxide & 25.9 & 57 & 56.2 & 15.6 & 18.6 & 14.5 \\
\hline $\mathrm{LiCl} / \mathrm{Cu}$-oxide & 49.5 & 80 & 20.6 & 0 & 10.2 & 10.2 \\
\hline LiCl/Zn-oxide & 22.0 & 49 & 42.6 & 26.3 & 15.2 & 9.4 \\
\hline
\end{tabular}

Reaction conditions: $\mathrm{T}=1,023 \mathrm{~K}, \mathrm{P}\left(\mathrm{CH}_{4}\right) / \mathrm{P}\left(\mathrm{O}_{2}\right)=2, \mathrm{P}\left(\mathrm{CH}_{4}\right)=5.1 \mathrm{kPa}$, and $\mathrm{W} / \mathrm{F}=0.167 \mathrm{~g} \cdot \mathrm{h} \cdot \mathrm{l}^{-1}$.

Table 3 Synthesis of Ethylene over NaCl/Mn-oxides at Different Pressures of Reactants

\begin{tabular}{|c|c|c|c|c|c|c|}
\hline $\begin{array}{l}\mathrm{P}\left(\mathrm{CH}_{4}\right)+\mathrm{P}\left(\mathrm{O}_{2}\right) \text {, atm } \\
\text { Catalyst weight, g } \\
\mathrm{CH}_{4} \text { conversion, \% } \\
\mathrm{O}_{2} \text { conversion, \% } \\
\text { Selectivity to hydrocarbons }\left(\geq \mathrm{C}_{2}\right), \%\end{array}$ & $\begin{array}{l}0.09 \\
0.40 \\
46.8 \\
99.4 \\
65.2\end{array}$ & $\begin{array}{l}0.19 \\
0.40 \\
46.1 \\
98.8 \\
56.0\end{array}$ & $\begin{array}{l}0.34 \\
0.40 \\
41.5 \\
99.5 \\
51.4\end{array}$ & $\begin{array}{l}0.64 \\
0.40 \\
38.9 \\
92.9 \\
45.5\end{array}$ & $\begin{array}{l}0.83 \\
0.40 \\
36.1 \\
97.4 \\
53.1\end{array}$ & $\begin{array}{l}1.00 \\
0.25 \\
32.0 \\
97.6 \\
48.9\end{array}$ \\
\hline $\begin{array}{l}\text { Yields, \% } \\
\text { (C, } \mathrm{H}_{4} \\
\mathrm{C}_{4,} \mathrm{H}_{6} \\
\mathrm{C}_{3} \mathrm{H}_{6} \\
\mathrm{C}_{4} \mathrm{H}_{8} \\
\text { Benzene+ Toluene } \\
\text { Total H. C. }\end{array}$ & $\begin{array}{r}25.7 \\
1.7 \\
0.5 \\
1.9 \\
0.8 \\
30.6\end{array}$ & $\begin{array}{r}19.8 \\
2.2 \\
0.6 \\
2.8 \\
0.4 \\
25.8\end{array}$ & $\begin{array}{r}16.8 \\
2.6 \\
0.7 \\
0.9 \\
0.4 \\
21.3\end{array}$ & $\begin{array}{r}14.2 \\
1.9 \\
0.9 \\
0.4 \\
0.2 \\
17.6\end{array}$ & $\begin{array}{r}14.9 \\
2.2 \\
1.1 \\
0.7 \\
0.3 \\
19.2\end{array}$ & $\begin{array}{r}11.9 \\
2.0 \\
0.9 \\
0.5 \\
0.2 \\
15.7\end{array}$ \\
\hline 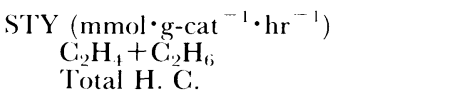 & $\begin{array}{r}9.2 \\
10.2\end{array}$ & $\begin{array}{l}14.7 \\
17.3\end{array}$ & $\begin{array}{l}23.4 \\
25.7\end{array}$ & $\begin{array}{l}36.7 \\
40.1\end{array}$ & $\begin{array}{l}50.4 \\
56.6\end{array}$ & $\begin{array}{l}64.0 \\
72.3\end{array}$ \\
\hline
\end{tabular}

Reaction conditions: $\mathrm{T}=1,023 \mathrm{~K} ; \mathrm{P}\left(\mathrm{CH}_{4}\right): \mathrm{P}\left(\mathrm{O}_{2}\right)=2: 1$, and total gas flow rate $=100 \mathrm{~m} l \cdot \mathrm{min}^{-1}$.

$(30.6 \%)$ ever reported. The $\mathrm{C}_{2}$-yield for $\mathrm{LiCl} / \mathrm{Ni}$ oxide increased to $28.9 \%$ when $\mathrm{W} / \mathrm{F}$ was increased to $0.34 \mathrm{~g} \cdot \mathrm{h} \cdot \mathrm{l}^{-1}$. The striking effect of $\mathrm{LiCl}$ on the $\mathrm{C}_{2} \mathrm{H}_{4}$-selectivity is shown in the last column of Table 2. The percentage of ethylene in the $\mathrm{C}_{2}$ compounds produced was greater than $90 \%$ for the LiCl-added oxides of $\mathrm{Ti}, \mathrm{Mn}, \mathrm{Co}, \mathrm{Ni}$, and $\mathrm{Cu}$. $\mathrm{NaCl}$ and $\mathrm{LiBr}$ also exerted similar favorable effects on the $\mathrm{C}_{2} \mathrm{H}_{4} / \mathrm{C}_{2} \mathrm{H}_{6}$ ratio. Table 3 shows the results of ethylene synthesis over the NaCladded (20 $\mathrm{mol} \%$ ) Mn-oxides at different pressures of the reactant. ${ }^{40)}$ As can be seen in the table, the main product was ethylene under all conditions tested. It is noteworthy that propylene, butene, benzene, and toluene were also produced. The yield of total hydrocarbons $\left(\geq \mathrm{C}_{2}\right.$ ) was quite high $(30.6 \%)$ when the pressure of the reactant was 0.09 atm. STYS of $\mathrm{C}_{2}$ compounds and total hydrocarbons $\left(\geq \mathrm{C}_{2}\right)$ increased linearly with increasing pressure of the reactant.

As demonstrated above, alkali halide-added transition metal oxides showed high catalytic activity for converting methane directly into ethylene. However, deactivation of the catalysts was a serious problem. $\mathrm{NaCl} / \mathrm{Mn}$-oxide in Table 3 was superior to $\mathrm{LiCl} / \mathrm{Ni}$-oxide because the lifetime of the former was much longer than that of the latter.
Regeneration of the used catalyst can easily be performed by adding a new alkali halide.

Fig. 10 shows the change in the $\mathrm{C}_{2} \mathrm{H}_{4} / \mathrm{C}_{2} \mathrm{H}_{6}$ ratio with time on stream for the reaction over LiCl $(20 \mathrm{~mol} \%$ )/Ni-oxide. Analysis of the effluent gas indicated the formation of $\mathrm{CH}_{3} \mathrm{Cl}$ during the reaction. Relative concentration of $\mathrm{CH}_{3} \mathrm{Cl}$ are also plotted in Fig. 10. Similar trends observed for the two curves strongly suggest that the $\mathrm{CH}_{3} \mathrm{Cl}$ plays an important role in the selective synthesis of ethylene.

\subsection{Role of Alkali Halides}

Weissman and Benson ${ }^{41)}$ reported that chlorine radicals catalyzed the formation of ethylene from methane at high temperatures in the gas phase. The observation that only alkali halides can enhance selective conversion of methane to ethylene suggests that halogen radicals supplied from the alkali halides play a significant role in the reaction. The results in Fig. 10 suggest the important role of $\mathrm{CH}_{3} \mathrm{Cl}$ for selective synthesis of ethylene. We have observed that $\mathrm{CH}_{3} \mathrm{Cl}$ catalyzed dehydrogenation of ethane to ethylene at temperatures above $923 \mathrm{~K}^{42)}$

A tentative reaction mechanism explaining the action of chlorine atom is as follows: ${ }^{42)}$

$$
2 \mathrm{CH}_{4}+1 / 2 \mathrm{O}_{2} \longrightarrow \mathrm{C}_{2} \mathrm{H}_{6}+\mathrm{H}_{2} \mathrm{O}
$$




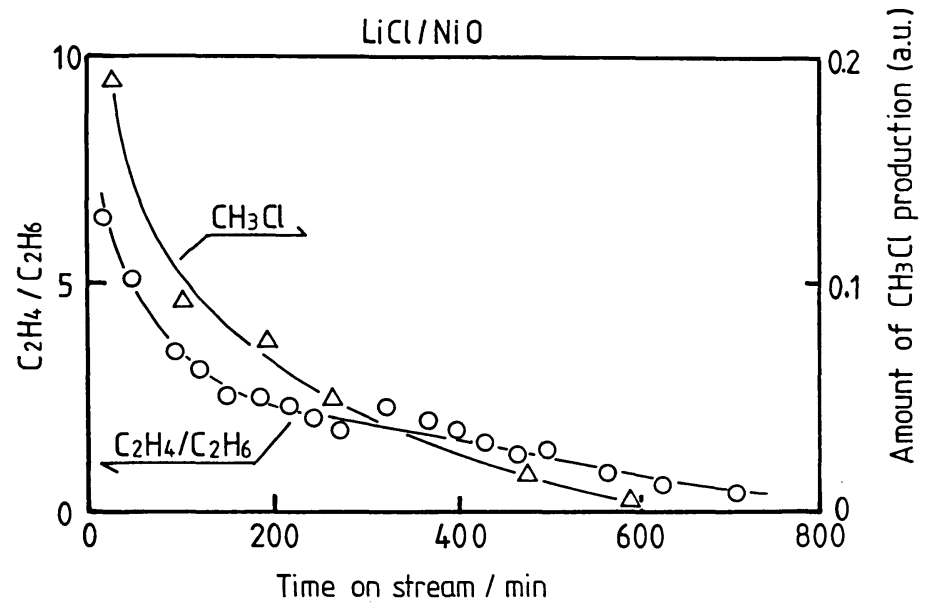

Reaction conditions : $\mathrm{T}=1,023 \mathrm{~K}, \mathrm{P}\left(\mathrm{CH}_{4}\right): \mathrm{P}\left(\mathrm{O}_{2}\right)=5: 2, \mathrm{P}\left(\mathrm{CH}_{4}\right)=10.1 \mathrm{kPa}, \mathrm{W} / \mathrm{F}=0.167 \mathrm{~g} \cdot \mathrm{h} \cdot \mathrm{l}^{-1}$.

Fig. 10 Changes in the $\mathrm{C}_{2} \mathrm{H}_{4} / \mathrm{C}_{2} \mathrm{H}_{6}$ Ratio and Relative Concentration of $\mathrm{CH}_{3} \mathrm{Cl}$ with Time on Stream of Reactants

$\mathrm{LiCl}+\mathrm{CH}_{4}+1 / 2 \mathrm{O}_{2} \longrightarrow \mathrm{LiOH}+\mathrm{CH}_{3} \mathrm{Cl}$

$\mathrm{CH}_{3} \mathrm{Cl} \longrightarrow \mathrm{CH}_{3} \cdot+\mathrm{Cl} \cdot$

$\mathrm{C}_{2} \mathrm{H}_{6}+\mathrm{Cl} \cdot \longrightarrow \mathrm{C}_{2} \mathrm{H}_{5} \cdot+\mathrm{HCl}$

(c)

$\mathrm{C}_{2} \mathrm{H}_{5} \cdot \longrightarrow \mathrm{C}_{2} \mathrm{H}_{4}+\mathrm{H}$.

$\mathrm{HCl}+\mathrm{H} \cdot \longrightarrow \mathrm{H}_{2}+\mathrm{Cl}$.

$\mathrm{HCl}+\mathrm{CH}_{3} \cdot \longrightarrow \mathrm{CH}_{4}+\mathrm{Cl}$.

Eq.(a) indicates the catalytic conversion of methane into ethane over alkali metal-added transition metal oxides. The role of aikali metals is to create compounded oxides of the alkali metal and the host transition metal oxides. ${ }^{43}$ ) The compounded oxides catalyze the formation of ethane very selectively. ${ }^{43)}$ The $\mathrm{CH}_{3} \mathrm{Cl}$ generated in reaction (b) liberates a chlorine atom in reaction (c). The $\mathrm{C}_{2} \mathrm{H}_{6}$ formed in reaction (a) would be converted quickly into $\mathrm{C}_{2} \mathrm{H}_{4}$ in reactions (d) and (e). Chlorine atoms are regenerated by reactions (f) and $(\mathrm{g})$. Thus, the chlorine atoms supplied from alkali chlorides catalyze the synthesis of $\mathrm{C}_{2} \mathrm{H}_{4}$ from $\mathrm{C}_{2} \mathrm{H}_{6}$ during the stay of the flowing gases in the hot reactor zone.

\section{Methane to Aromatics}

Conversion of methane into aromatic hydrocarbons would open a new route for synthesizing highly functionalized chemicals directly from natural gas. However, the challenging work to convert methane directly into aromatics by partial oxidation has not yet been successful, except the cases in which $\mathrm{N}_{2} \mathrm{O}$ as a mild oxidizing agent was used. $^{31), 32)}$ We can readily recognize that this difficulty arises from the large difference in the reactivities of methane and aromatic hydrocarbons. Under severe oxidation conditions that can activate methane in the presence of $\mathrm{O}_{2}$, there may be but a
Table 4 Synthesis of Higher Hydrocarbons over NaCl/ Mn-oxide/Silicalites

\begin{tabular}{l|rr}
\hline $\mathrm{P}\left(\mathrm{CH}_{4}\right) / \mathrm{P}\left(\mathrm{O}_{2}\right)$ & 2.5 & 1.7 \\
$\mathrm{CH}_{4}$ conversion, \% & 43.9 & 52.7 \\
Hydrocarbon selectivity, \% & 63.4 & 46.4 \\
Yields, \% & 22.8 & 19.2 \\
$\mathrm{C}_{2} \mathrm{H}_{4}$ & 1.7 & 0.9 \\
$\mathrm{C}_{2 .} \mathrm{H}_{6}$ & 2.4 & 2.8 \\
$\mathrm{C}_{3} \mathrm{H}_{6}+\mathrm{C}_{4} \mathrm{H}_{8}$ & 1.0 & 1.6 \\
Benzene + toluene & 27.8 & 24.5 \\
\hline Total H. C. & \\
\hline
\end{tabular}

Reaction conditions: $\mathrm{T}=1,023 \mathrm{~K}, \mathrm{P}\left(\mathrm{CH}_{4}\right)+\mathrm{P}\left(\mathrm{O}_{2}\right)=23$ $\mathrm{kPa}$, Flow rate $=61 \mathrm{ml} \cdot \mathrm{min}^{-1}$, and catalyst weight $=3.0 \mathrm{~g}$

slight chance of getting aromatics without converting them wholly into $\mathrm{CO}_{2}$.

As demonstrated earlier (Table 3), the NaCladded Mn-oxide formed aromatics though in small yields $(\leq 0.8 \%)$ during partial oxidation of methane in the presence of oxygen. The yields were improved when the $\mathrm{NaCl} / \mathrm{Mn}$-oxide was supported on silicalites as shown in Table 4. This observation implies that ZSM-5 type structure might exert a favorable effect on the synthesis of aromatics.

It is reported that light paraffinic hydrocarbons can be converted into aromatics in the absence of oxygen using the ZSM-5 zeolites ion-exchanged with $\mathrm{H}^{+}, \mathrm{Ga}^{3+}$ and $\mathrm{Al}^{3+}$. ${ }^{44), 45)}$ Thus, we can expect that the combination of two types of catalysts, one for oxidative coupling of methane (coupling catalyst) and the other for oligomerization of the coupled products and for subsequent cyclization to aromatic hydrocarbons (aromatization catalyst), may increase the yields of aromatics directly from methane by passing the mixture of methane and oxygen through the respective catalyst beds.

Deep oxidation of $\mathrm{CH}_{4}$ occurred exclusively 
when the aromatization catalyst was used alone in the presence of $\mathrm{O}_{2}$. The coupling catalyst mixed with the aromatic catalyst did not give any aromatics either. Therefore, experiments were carried out with the reactant $\left(\mathrm{CH}_{4}\right.$ and $\left.\mathrm{O}_{2}\right)$ passing through the two catalysts, coupling and aromatization, packed in series in the reactor with some space between the each catalyst bed. ${ }^{46)}$ The results obtained are shown in Fig. 11. The combinations of $\mathrm{Li}_{2} \mathrm{CO}_{3} / \mathrm{Sm}_{2} \mathrm{O}_{3}, \mathrm{LiCl} / \mathrm{Ni}$-oxide, and $\mathrm{NaCl} / \mathrm{Mn}$-oxide (coupling catalysts) with Ga-ZSM5 (aromatization catalyst) in such series produced significant amounts of aromatics as had been expected. For all catalyst combinations in Fig. 11, the selectivity to aromatics was greater than $6 \%$. $\mathrm{LiCl} / \mathrm{Ni}$-oxide and $\mathrm{NaCl} / \mathrm{Mn}$-oxide with $\mathrm{Ga}$ ZSM-5 $(\mathrm{Si} / \mathrm{Al}=25)$ gave fairly high selectivities $(>16.3 \%)$ to and yields $(>5.5 \%)$ of aromatics. Considerable amounts of light hydrocarbons produced by these coupling catalysts remained unreacted in the effluent gas. Therefore, yields of aromatics can be improved if catalysts having higher catalytic activities for conversion of light hydrocarbons to aromatics could be developed. Moreover, better reactor design and better reaction conditions such as $\mathrm{P}\left(\mathrm{CH}_{4}\right) / \mathrm{P}\left(\mathrm{O}_{2}\right)$ ratio, temperature control of and distance between the each

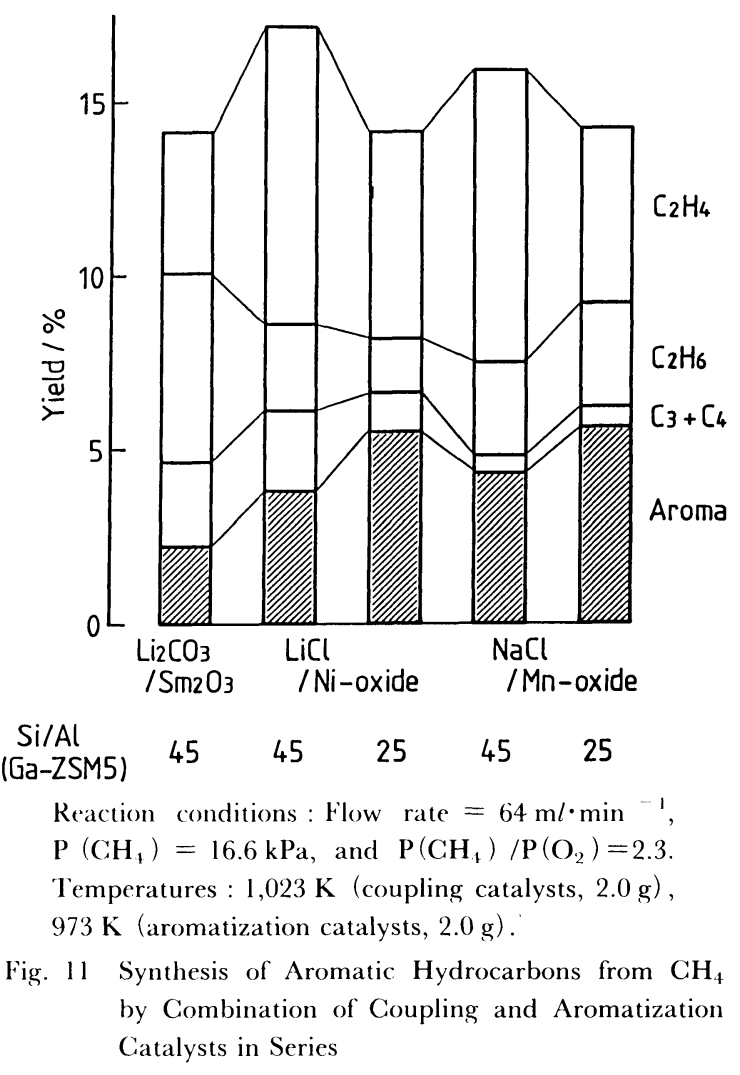

catalyst bed, and flow rate of reactant should also enhance aromatics yields.

\section{Some Concluding Remarks}

This paper has covered only one of the approaches by which methane is partially oxidized to higher hydrocarbons. Other important products synthesized directly from methane are methanol and formaldehyde. Detailed information about the past and recent works on this subject is available. ${ }^{5), 6), 8)}$ Other topics of methane activation and functionalization are also receiving serious considerations. ${ }^{3), 4), 7)}$ Methane chemistry, based on its ubiquitous and secure supplies, presents great opportunities and challenges for heterogeneous and homogeneous catalysis.

The catalysts described in this paper may provide a new route to the production of ethylene and higher hydrocarbons from methane. However, the results to date, while encouraging, are still short of commercial realization. However, if progress on catalysts of greater conversion, selectivity, and lifetime continues, the new route can achieve commercial realization.

\section{References}

1) Chang, C. D., Silvestri, A. J., J. Catal., 47, 249 (1977).

2) Chang, C. D., Catal. Rev.-Sci. Eng., 26, 323 (1984).

3) Shilov, A. E., "Activation of Saturated Hydrocarbons by Transition Metal Complexes”, (1984), D. Reidel Publishing Company.

4) Otake, M., Imada, Y., Shokubai (Catalyst), 27, 299 (1985).

5) Foster, N. R., Appl. Catal., 19, 1 (1985).

6) Gesser, H. D., Hunter, N. R., Chem. Rev., 85, 235 (1985).

7) Crabtree, R. H., Chem. Rev., 85, 245 (1985).

8) Pitchai, R., Klier, K., Catal. Rev., 28, 13 (1986).

9) Keller, G. E., Bhasin, M. M., J. Catal., 73, 9 (1982).

10) Hinsen, W., Bytyn, W., Baerns, M., Proc. 8th Int. Congr. Catal., 3, 581 (1984).

11) Otsuka, K., Jinno, K., Morikawa, A., Chem. Lett., 1985, 499.

12) Ito, T., Lunsford, J. H., Nature (London), 311, 721 (1985).

13) Ito, T., Wang, J.-X., Lin, C.-H., Lunsford, J. H., J. Am. Chem. Soc., 107, 5062 (1985).

14) Otsuka, K., Liu, Q., Hatano, M., Morikawa, A., Chem. Letl., 1986, 467.

15) Otsuka, K., Liu, Q., Hatano, M., Morikawa, A., Chem. Lett., 1986, 903

16) Otsuka, K., Liu, Q., Morikawa, A., J. Chem. Soc., Chem. Commun., 1986, 586

17) Otsuka, K., Liu, Q., Morikawa, A., Inorg. Chim. Acta, 118, L23 (1986).

18) Otsuka, K., Jinno, K., Morikawa, A., J. Catal., 100, 353 (1986).

19) Otsuka, K., Jinno, K., Inorg. Chim. Acta, 121, 237 (1986). 
20) Imai, T., Tagawa, T., J. Chem. Soc., Chem. Commun., 1986, 52; Tagawa, T., Imai, H., 52th JCS Meeting (Japan), 2C40 (1986)

21) Aika, K., Moriyama, T., Takasaki, N., Iwamatsu, E., J. Chem. Soc., Chem. Commun., 1986, 1210.

22) Asami, K., Hashimoto, S., Shikada, T., Fujimoto, K., Tominaga, H., Chem. Lett., 1986, 1233.

23) Matsuura, I., Utsumi, Y., Nakai, M., Doi, T., Chem. Letl., 1986, 1981.

24) Emesh, I. T. A., Amenomiya, Y., J. Phys. Chem., 90, 4785 (1986)

25) Yamagata, N., Tanaka, K., Sasaki, S., Okazaki, S., Chem. Lett., 1987, 81.

26) U. S. Pat. 4,499,322 (1985), 4,499,323 (1985); WO 85/ 04821 , WO 85/04867

27) Otsuka, K., Komatsu, T., Chem. Lett., 1987, 483.

28) Driscoll, D. J., Martir, W., Wang, J.-X., Lunsford, J. H., J. Am. Chem. Soc., 107, 5062 (1985).

29) Liu, R.-S., Iwamoto, M., Lunsford, J. H., J. Chem. Soc., Chem. Commun., 1982, 78

30) Liu, H.-F, Liu, R.-S., Liew, K. Y., Johnson, R. E., Lunsford, J. H., J. Am. Chem. Soc., 106, 4117 (1984).

31) Shepelev, S. S., Ione, K. G., React. Kinet. Catal. Lett., 23, 319 (1983).

32) Anderson, J. R., Tsai, P., Appl. Catal., 19, 141 (1985).

33) Otsuka, K., Nakajima, T., Inorg. Chim. Acta, 120, L27
(1986).

34) Otsuka, K., Nakajima, T., J. Chem. Soc., Faraday Trans. 1, 83, 1315 (1987)

35) Vardanyan, I. A., Yan, S., Nalbandyan, A. B., Kinet. Katal., 22, 845 (1981)

36) Walker, R. W., "Reaction Kinetics", Vol. 1, 161 (1975), and refs. therein, The Chemical Society London.

37) Lin, C.-H., Campbell, K. D., Wang, J.-X., Lunsford, J. H., J. Phys. Chem., 90, 534 (1986).

38) Wang, J.-X., Lunsford, J. H., J. Phys. Chem., 90, 3890 (1986).

39) Otsuka, K., Said, A. A., Jinno, K., Komatsu, T., Chem. Lett., 1987, 77.

40) Otsuka, K., Komatsu, T., J. Chem. Soc., Chem. Commun., 1987, 388 .

41) Weissman, M., Benson, S. W., Intern. J. Chem. Kinet., 16, 307 (1984).

42) Otsuka, K., Hatano, M., Komatsu, T., Methane Conversion Symposium, New Zealand, (1987)

43) Hatano, M., Otsuka, K., submitted for publication.

44) Anderson, J. R., Foger, K., Mole, T., Rajadhyaksha, R. A., Sanders, J. V., J. Catal., 58, 14 (1979).

45) Chu, P., U. S. Pat., 4,120,910 (1978); Chester, A. W., Chu, Y. F., U. S. Pat., 4,350,835 (1982).

46) Otsuka, K., Komatsu, T., Chem. Lett., 1986, 1955 
要旨

\title{
メタンから炭化水素 $\left(\geq \mathbf{C}_{2}\right)$ の直接合成
}

\author{
大塚潔
}

東京I:業大学化学:L学科, 152 東京都目黑区大岡川 2-12-1

近年，化学】業原料としてのメタンの新しい利用法について 関心が高まっている。水蒸気改質により命成ガスとすることな しに,メタンを部分酸化で淔接目的化合物に転換することがで きれば，エネルギーの節約とプロセスの簡略化から，その工業 的意義は大きい。本稿では, メ夕ンから淔接 $\mathrm{C}_{2}$ 以上の炭化水 素への接触的転換友心について著者らの研究を紹介した。取上 げた反忍は，メタンの酸化カップリング文伈による $\mathrm{C}_{2}$ 炭化水 素 $\left(\mathrm{C}_{2} \mathrm{H}_{6}+\mathrm{C}_{2} \mathrm{H}_{4}\right)$ の令成，メタンからエチレンの選択的命成, および芳香族䈐化水素の令成である。

酸化カップリング仪心に存効な触媒を探索した結果, 希土類 酸化物, 中でも $\mathrm{Sm}_{2} \mathrm{O}_{3}$ が活性, $\mathrm{C}_{2}$ 選択性，および触媒寿命 の梷で最も優れた触媒であることがわかった（Figs. 1, 2, 3, Table 1)。速度論的研究 (Figs. 4, 6, 7) から, $\mathrm{Sm}_{2} \mathrm{O}_{3}$ 触媒上 では, メタンの活性化は分子状活性酸素種 (たぶん $\mathrm{O}_{2}{ }^{2-}$ ) に よって引き起こされることを示唆した。酸化剤として $\mathrm{N}_{22} \mathrm{O}$ を 用いてメタンのカップリング度をを行い， $\mathrm{O}_{2}$ を酸化㓮として 用いた結果と比較した (Figs. 8, 9)。メタンの酸化カップリン
グ反㐫用酸化剤としては， $\mathrm{O}_{2}$ が優れていることがわかった。 エチレンの選択的合成には, 金属酸化物触媒にハロゲン化ア ルカリを添加すると良いことがわかった。特に $\mathrm{LiCl} や \mathrm{NaCl}$ を第一遷移金属酸化物に添加した触媒は, 高い収率 $(9 \sim 28 \%)$ でエチレンを合成することがわかった（Tables 2,3）。アルカ リ金属は遷移金属酸化物との間に, エ夕ンの生成に高活性な複 命酸化物を形成する。ハロゲン化アルカリから生成したハロゲ ン原子は, エタンの脱水素反応を気相で触媒しエチレンを生成 する。ハロゲン化アルカリの以上の二つの働きにより, メタン からエチレンの選択的合成が可能となる。

メタンからベンゼンとトルエンの合成には, $\mathrm{NaCl} / \mathrm{Mn}$-酸化 物/シリカライト触媒が有効である (Table 4)。メタンの酸化 カップリング用触媒と $\mathrm{C}_{2}$ 炭化水素の芳香族化用触媒である Ga-ZSM-5 ゼオライトを二段に組合せると, 比較的高い選択率 (>16.3\%) と収率（>5.5\%) で芳香族炭化水素が合成できる ことを示した (Fig. 11)。

\section{Keywords}

Aromatization, Conversion, Methane, Oxidative coupling, Oxide catalyst, Partial oxidation 